\title{
Black Rot of Orchids Caused by Phytophthora palmivora and Phytophthora cactorum 1
}

\author{
R.A. Cating, A. J. Palmateer, C. M. Stiles, P. A. Rayside, and D. A. Davison²
}

Black rot of orchids can be caused by several pathogens. Frequently, black rot is caused by Phytophthora cactorum or Phytophthora palmivora (Hine, 1962; Uchida, 1994; Orlikowski and Szkuta, 2006). Although P. cactorum and P. palmivora are very similar, they can be identified by morphological characteristics or by the use of molecular diagnostic techniques (Tsai et al., 2006). Another organism, Pythium ultimum can also cause black rot. Pythium ultimum can be differentiated from $P$. cactorum and $P$. palmivora based on morphology; however, $P$. ultimum is less commonly seen in orchids. Although Phytophthora and Pythium are different genera, their life cycles, morphology, epidemiology, and control are similar.

\section{Host Range}

Phytophthora palmivora and Phytophthora cactorum have been known to cause disease on several different orchid genera, including Aerides, Ascocenda, Brassavola, Dendrobium, Gongora, Maxillaria, Miltonia, Oncidium, Paphiopedilum, Phalaenopsis, Rhynchostylis, and Schomburgkia, as well as some less commonly grown genera (Alfieri et al.,1994; Orlikowski and Szkuta, 2006). However, the disease is frequently seen on Cattleya orchids and their hybrids, such as Brassocattleya and Laeliocattleya.

\section{Symptoms}

Small black lesions can be observed on the roots or basal portions of the pseudobulbs. As the lesions age, they enlarge and may engulf the entire pseudobulb and leaf (Figures 1, and 2). The pathogen can spread through the rhizome to other portions of the plant. Eventually, the entire plant will be killed.

\section{Diagnosis}

Diagnosis of black rot caused by Phytophthora cactorum and Phytophthora palmivora is based on morphology of the pathogen or through the use of molecular techniques. Identification is based on characteristics of the mycelium, shape of zoosporangia (asexual reproductive structures) and the presence and shape of oospores (sexual reproductive structures).

1. This document is PP260, one of a series of the Plant Pathology Department, Florida Cooperative Extension Service, Institute of Food and Agricultural Sciences, University of Florida. Original publication date, January 2009. Visit the EDIS Web site at http://edis.ifas.ufl.edu.

2. R.A. Cating, graduate research assistant, Tropical Research and Education Center (TREC)--Homestead, FL; A. J. Palmateer, assistant professor, Plant Pathology Department, TREC; C. M. Stiles, assistant professor, and P. A. Rayside, senior biological scientist, Plant Pathology Department, University of Florida, Gainesville, FL; and D. A. Davison, biological scientist III, Florida Department of Agriculture and Consumer Services, Division of Plant Industry, Tallahassee, FL.

The Institute of Food and Agricultural Sciences (IFAS) is an Equal Opportunity Institution authorized to provide research, educational information and other services only to individuals and institutions that function with non-discrimination with respect to race, creed, color, religion, age, disability, sex, sexual orientation, marital status, national origin, political opinions or affiliations. U.S. Department of Agriculture, Cooperative Extension Service, University of Florida, IFAS, Florida A. \& M. University Cooperative Extension Program, and Boards of County Commissioners Cooperating. Larry Arrington, Dean 


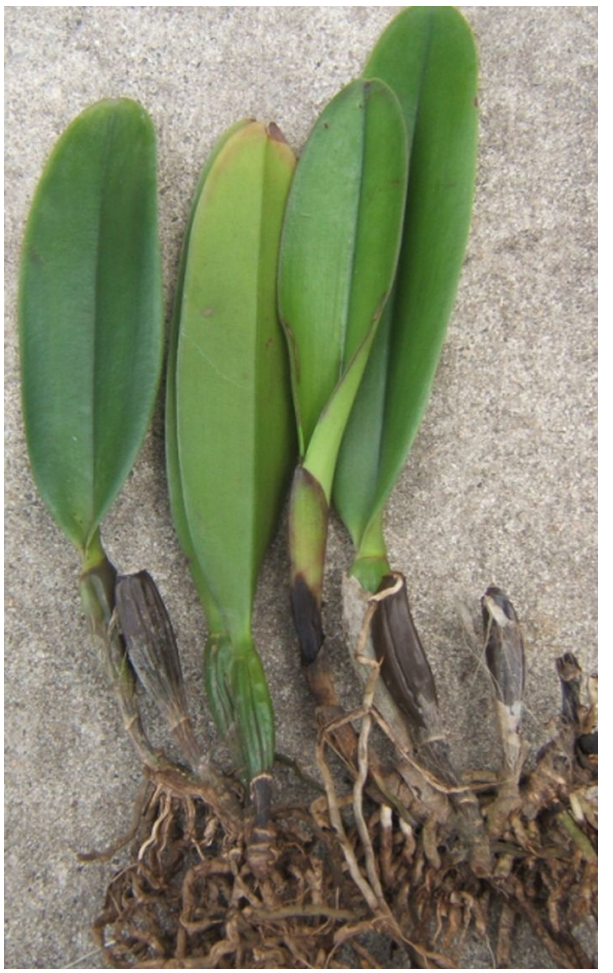

Figure 1. Cattleya sp. Black rot symptoms caused by Phytophthora cactorum. Credits: R. A. Cating

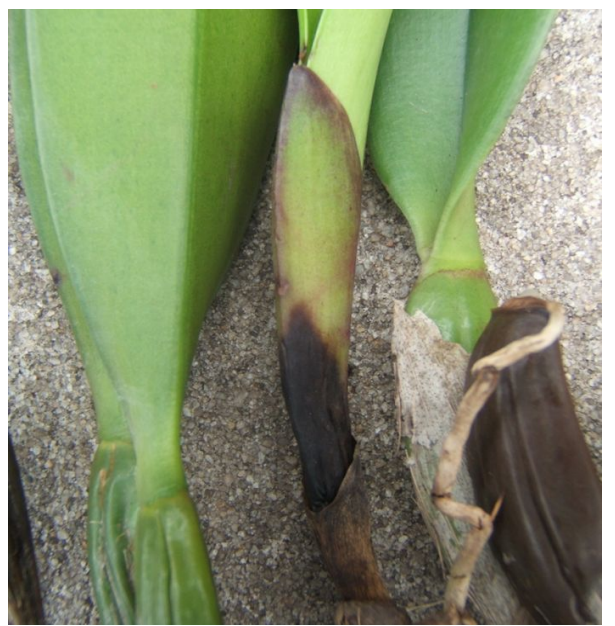

Figure 2. Cattleya sp. Close up view of black rot symptoms caused by Phytophthora cactorum. Credits: R. A. Cating

If zoosporangia are present, and are roughly lemon-shaped with a short pedicel (stalk at the base of the spore) after the zoosporangium has been detached and contains a papilla (small swelling on the tip of the spore, see arrow in Figure 7), one can be fairly confident it is a member of the Phytophthora genus.

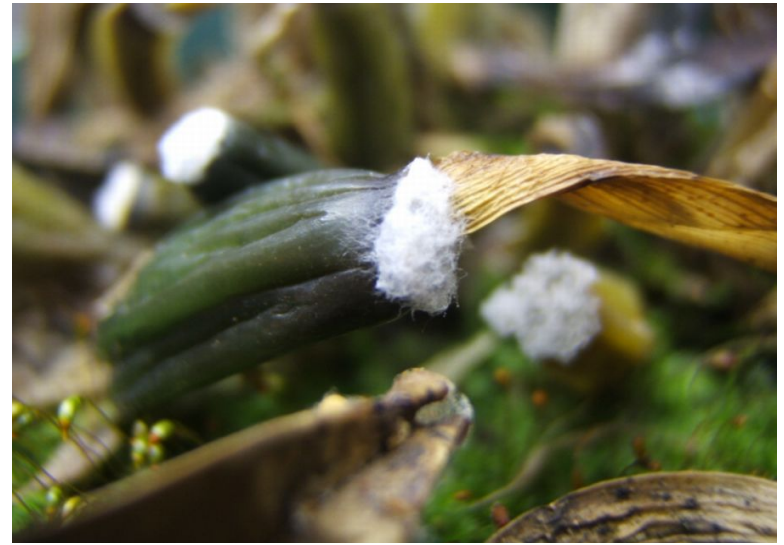

Figure 3. Cattleya hybrid. White mycelium containing sporangia of Phytophtora palmivora can be seen on the end of pseudobulbs. Credits: R. A. Cating

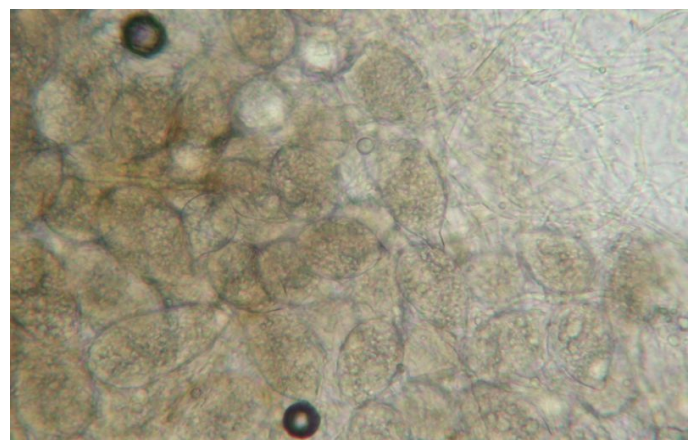

Figure 4. Sporangia of Phytophtora palmivora taken directly from plant tissue observed in Figure 3. Credits: R. A. Cating

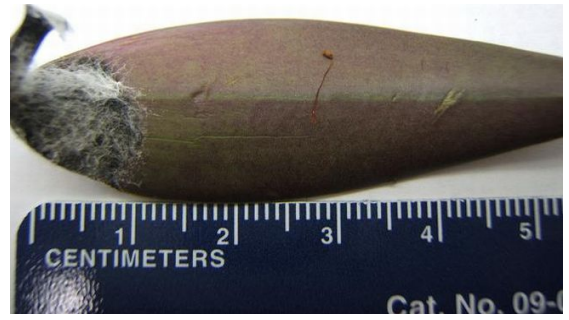

Figure 5. Cattleya hybrid. White hyphae containing sporangia can be seen on basal portion of leaf. Credits: R. A. Cating

In most cases, identifying the pathogen to genus will provide enough information to identify proper prevention and control strategies.

\section{Management}

\section{Phytophthora cactorum and Phytophthora} palmivora are considered water molds and require water to spread the spores and to germinate on new hosts. The spores can easily spread in irrigation water and can splash from one plant to another during watering (Uchida, 1994). In addition, zoospores, 


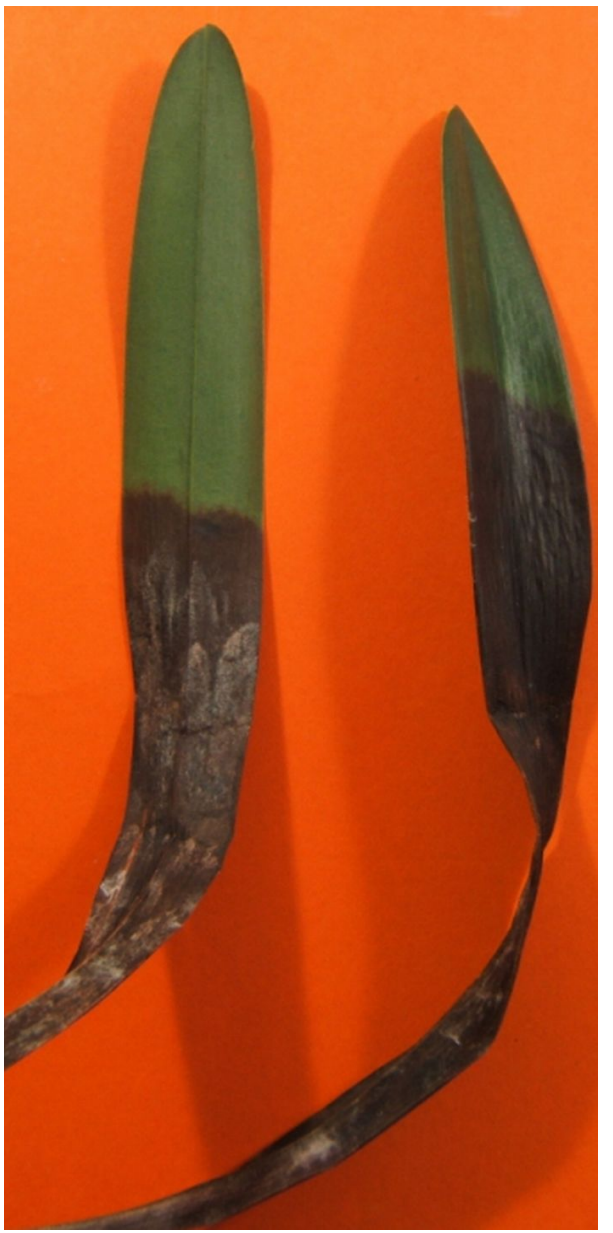

Figure 6. Oncidium hybrid with black-rot caused by Phytophthora palmivora. Credits: R. A. Cating

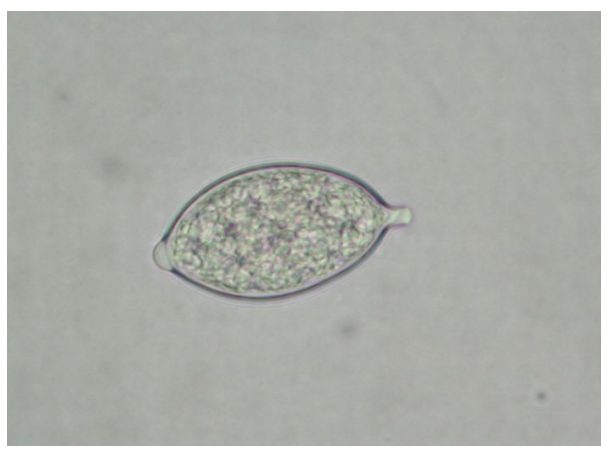

Figure 7. Sporangium of Phytophthora palmivora. Sporangium is papillate and ovoid with a short pedicel. Credits: R. A. Cating

which are motile, are normally considered the infective spore and can move readily when free water is available. Therefore, it is crucial to remove infected plants immediately to prevent further spread, reduce periods of prolonged wetness, and provide adequate ventilation. Elevating the plants above the ground or keeping them on a solid surface can also help prevent infections. To prevent black rot, growers should also do the following:

\section{Nursery Sanitation Recommendations for Phytophthora}

Fungicides should be considered as a tool for managing Phytophthora and if not used properly (according to the manufacturer's label) they will not be effective or may cause more harm than benefit. However, they are your primary defense in an existing crop and provide at least some level of management when used appropriately.

Getting Phytophthora under control requires a longer-term strategy and actions that focus on changing and improving procedures and materials to reduce the opportunity for spread or reintroduction of the pathogen. Successful management of Phytophthora in a nursery has been accomplished in the past when dramatic measures were undertaken. Some growers keep a clean laboratory or surgical room in mind as they think through their nursery sanitation procedures.

\section{Fungicide Options}

Preventative applications of foestyl-AL (Aliette, Flanker, Prokoz Avalon), potassium phosphite (Alude, Fungi-Phite, Topaz), propamocarb hydrochloride (Banol), trifloxystrobin (Compass), Bacillus subtilis QST 713 (Rhapsody), dimethomorph (Stature), mefenoxam (Subdue), etridiazole (Terrazole 35\%) may aid in reducing disease spread, but only complete control can be achieved if the infected planting material is destroyed.

For more information on disease management and chemical recommendations refer to Professional Disease Management Guide for Ornamental Plants or Homeowner's Guide to Fungicides for Lawn and Landscape Disease Management.

\section{Growing Media and Storage:}

Use only unopened bagged growing media stored on a covered paved surface that can be periodically washed down with a 1:3 ratio of bleach (sodium hypochlorite) to water. It is likely that the 
pathogen will move into your growing media if not bagged or completely covered.

Each use, use only disinfected tools and hands (disposable latex gloves that can be purchased at the grocery store or professional cook equipment stores work well). Bleach works by oxidizing or destroying the molecular bonds in microorganisms. Store purchased bleach solutions are now usually $6 \%$ sodium hypochlorite. The older non-concentrated versions are probably around 5\% solutions. Avoid mixing bleach with acids or toxic chlorine gas may result. Always use with good ventilation.

\section{Containers:}

Store new pots in sanitized areas similar to the growing media storage area. Your best option is to always use new potting containers, but if this is not feasible submerge potting containers in a 1:3 ratio of bleach (sodium hypochlorite) to water with agitation for a minimum of 10 minutes.

\section{Bench Sanitation:}

Make sure that bench surfaces are at high enough above the soil surface to avoid splashing from the ground below.

Sanitize all bench surfaces and tools used to prune or work with plants before each use. Remove or sanitize any surfaces that may drip water onto crop. Bleach dunking will cause steel to rust. Some growers handle this by dipping in bleach and then dunking in oil after drying.

Examples of disinfectants for tools and benches include: 1) $25 \%$ chlorine bleach (3 parts water and 1 part bleach; 2) 25\% pine oil cleaner (3 parts water and 1 part pine oil); 3) 50\% rubbing alcohol (70\% isopropyl; equal parts alcohol and water); 4) $50 \%$ denatured ethanol (95\%; equal parts alcohol and water); 5) 5\% quaternary ammonium salts. Soak tools for 10 minutes and rinse in clean water.

Do not mix quaternary ammonia with bleach. The wood portions of your bench may be very difficult to sanitize because they are porous. Scrubbing to remove algae, scum, mildew and dirt before treating may help.

\section{Water Supply and Hand Watering:}

Well and not surface water should be used unless disinfected.

If hand watering is utilized, be sure to sanitize the hose and water wands with bleach solution and hang in areas where the ends of the hose or wands will not contact soil of other potentially contaminated surfaces.

\section{New Plants Brought Into Nursery:}

Any new plants brought into the nursery should be kept isolated (including tools and continuous bench space used for these new plants) from other plants for at least 6 weeks to observe any disease or pest symptoms, and to avoid contamination with other crops.

\section{Other:}

Do not forget about other potential contamination surfaces like plant transport trailer or cart surfaces.

\section{Literature Cited}

- Alfieri, S. A., Jr., Langdon, K. R., Kimbrough, J. W., El-Gholl, N. E., and Wehlburg, C. 1994. Diseases and Disorders of Plants in Florida. Florida Department of Agriculture \& Consumer Services, Division of Plant Industry, Bulletin 14.

- Erwin, D. C. and Ribeiro, O. K. 1996. Phytophthora diseases worldwide. APS Press, St. Paul, Minnesota.

- Hine, R. B. 1962. Pathogenicity of Phytophthora palmivora in the Orchidaceae. Plant Dis. Rep. 46: 643-645.

- Orlikowski, L. B. and Szkuta, G. 2006. Phytophthora rot of some orchids-new disease in Poland. Phytopathol. Pol. 40: 57-61.

- Tsai, H.-L., Huang, L.-C., Ann, P.,-J., and Liou, R., -F. 2006. Detection of orchid phytophthora disease by nested PCR. Botanical Studies 47:379-387. 
- Uchida, J. Y. 1994. Diseases of Orchids in Hawaii. Plant Disease. 78: 220-224 